\title{
The Psalms as hymns in a liturgical CONTeXt
}

Author:

Cas J.A. $\operatorname{Vos}^{1}$

\section{Affiliation:}

${ }^{1}$ Unit for Creative Writing and Faculty of Theology, University of Pretoria, South Africa

Correspondence to:

Cas J.A. Vos

e-mail:

cas.vos@up.ac.za

\section{Postal address:}

The Dean, Faculty of Theology, University of Pretoria, Lynnwood Road, Hatfield 0083, Pretoria South Africa

Keywords: psalms; liturgy; psalter; hymns; Book of Psalms

\section{Dates:}

Received: 22 July 2008

Accepted: 10 Feb. 2009

Published: 02 Mar. 2009

How to cite this article: Vos, C.J.A., 2009, 'The

Psalms as hymns in a liturgical context', HTS Teologiese Studies/ Theological Studies 65(1), Art. \#105, 6 pages. DOI: 10.4102/hts.v65i1.105

\section{This article is available} at:

http://www.hts.org.za

(c) 2009. The Authors. Licensee: OpenJournals Publishing. This work is licensed under the Creative Commons Attribution License.

\section{ABSTRACT}

In many ways, the psalms fulfil a bridging function between divergent denominations that previously avoided each other. In the Hebrew text of the Psalter, most of the psalms have specific titles. However, none of these originated with the original psalms. Instead, they offer instruction for the reader concerning the process that led to the compilation of the Psalms in a collection. The psalms are more than liturgy, and liturgy is more than psalms. Therefore, the psalms cannot be clothed in liturgical vestments. Hymns that occur in the Book of Psalms are the focus of this article. It is clear that the praise in the hymns follows different patterns. The article aims to explore the liturgical influence of the psalms as hymns in a liturgical context.

\section{FIRST NOTES}

In this article, the influence of the psalms as hymns in a liturgical context will be the subject of discussion. This requires us to focus on the Psalter as hymnal.

\section{THE BRIDGING FUNCTION OF THE PSALMS}

In many ways, the Psalms fulfil a bridging function between divergent denominations that previously avoided each other. The psalms are songs which, in Judaism and in Christianity - in both the western and eastern Churches; in both Roman Catholicism and among Protestants - have obtained a key position in the liturgies of worship (Kaspar 1999:96; Schuman 1998b:374-375; Schuman 2008:27-32; Vos 2005:335). The psalms connect people from different parts of the world, different traditions and from different historical periods. The singing of psalms during worship is a constant reminder of the roots of Israel, Judaism, the temple and the synagogue (Barnard 1985:66-102; Schuman 1995; Schuman 1998b:375; Vos 2005:336).

\section{INFLUENCE OF PSALMS ON LITURGY}

The psalms are more than liturgy, and liturgy is comprised of more than merely psalms. Therefore, the psalms cannot simply be clothed in liturgical vestments. To distinguish the liturgical character of the psalms, different liturgical aspects should be considered.

The psalms have been spared from criticism more than other parts of the Old Testament. A reason for this is that the psalms started to bear the stamp of the piety of the Church very early on, and also belonged to the official liturgy of the Church (Zenger 1997:15). Yet, there were objections to certain psalms, especially the 'vindictive psalms', a prime example of which is Psalm 137.

The thesis that the Psalter was the 'hymnal of the Second Temple' has been refuted. However, the levitical choirs sang certain psalms for the people during the daily tamid sacrifice, and also at certain ceremonies on festival days, standing on the stairs leading from the Court of the Women to the Court of the Men. However, the number of such psalms is limited, and the priests in the cult proper recited other texts, when they did not carry out their duties in complete silence (Lohfink 2000:145; Groenewald 2003:148, 270; Braulik 2003:316).

The Psalter entered Christian worship only towards the end of the second century, and then only in individual psalms. At most we may surmise the use of psalms in ritual (Zenger 1997:28) by the Jewish group of Therapeutae, who lived in Egypt (Lohfink 2000:145). The Book of Psalms, however, remains the book in the Bible which exerted the greatest influence on the liturgy, not only in Old Testament times, but also in the Jewish and Christian churches.

The new interest in the liturgy prompted questions regarding the meaning and function of the psalms in the liturgy (Schuman 1998a:165; 1998b:377-378; 2001:250-252). In the Ecumenical Protestant Churches, reference is made in the liturgy to 'the psalm for this Sunday', which usually determines the pattern of the service in terms of the liturgical theme for the year. This is then given out as the proprium, together with a specific text as a refrain and the 'prayer for the Sunday' (Monshouwer 1998:423-449; Schuman 1998a:166-167).

The influence of the psalms on liturgy manifested itself especially on four levels, namely the psalms as a reader, a prayer book, a book of meditation and a book of songs.

\section{THE PSALMS AS HYMNAL}

\section{Psalm titles}

In the Hebrew text of the Psalter, most of the psalms bear clear titles. The older translations like the Septuagint, Vulgate and Peshitta tend to expand on the Hebrew text, or to add a new title where a title was lacking. The Targum, the free, descriptive translation in Aramaic, contains very expansive titles (Zenger 1997:28; cf. Schuman 2008:52-53).

Not one of the titles of the psalms belongs to the actual time of inception, hence directions are given regarding the compilation of the single psalms into a collection. The compilation shows signs of the 
association between the Old Testament and various psalms, while the spirituality is revealed of the group that prayed and meditated on these psalms (Leuenberger 2004; Vos 2005:44-49; Zenger 1997:28).

Many of the titles suggest the musical form a psalm should take. Indications are also given of the melody in which a psalm should be sung. The melodies of known folk songs were used as a basis (Zenger 1997:28-29). The melody, '(D)eath of a Son', can be linked to Psalm 9, and Psalm 57 was sung to the melody of '(D)o not Destroy!' Directions are also given for the instrumental accompaniment, e.g. 'with stringed instruments' (Ps 4), 'with flute' (Ps 5) and 'on an eight-stringed harp, with bass voice' (Ps 6). It is supposed that the compiler did not mean these indications to be technical directions. The directions for Psalm 6 indicate that the psalm was prayed/sung by those who were longing for the messianic times and, according to the rabbinical tradition, the eight-stringed harp was the instrument of these times (Zenger 1997:29).

Other titles suggest either the real, or the merely fictional cultic use of a psalm. Psalm 30 is recommended 'for the dedication of the temple,' Psalm 92 'for the Sabbath day' and Psalm 100 'for thanksgiving.' Such would be the directions for the real use of the psalms in the cult of the Second Temple, especially because it is more likely that the psalms originated from other situations in life (Zenger 1997:30; see also Groenewald 2003:148, 270). These headings therefore indicate a change in 'Sitz im Leben'.

In most cases, the titles of the psalms refer to the names of the groups or individuals to whom the psalms were connected. A psalm is linked to David 73 times, 12 times to Asaph (a prominent Levite of the post-exilic period, for whom a guild of temple musicians is named), twice to Solomon, four times to the Jeduthun, and once to Moses, Heman and Etan (Zenger 1997:30; see also Jonker 2004:103-113). 'The sons of Korah' and 'for the sons of Korah' could be understood as meaning a psalm from the collection of the sons of Korah. However, the mention of Moses or David was intended as an editorial indication and explanation only; it was not intended as historical information. The supplicant should be able to imagine how and why this psalm (Ps 90) was prayed by Moses or David, because of the allusion in line 3 to Genesis 3:19. The supplicant should then also be able to pray the psalm with Moses or David in communal prayer (Zenger 1997:30).

In Chronicles, David is neither a supplicant nor a singer of psalms. $\mathrm{He}$ is the founder and organiser of the temple music, probably even the inventor of instruments, as well as the commissioner for the writing of psalms and their setting to music (Braulik 1995:69; Zenger 1998:41). The David of the psalms (with the exception of Psalm 30) does not stand in any liturgical context. On the contrary, his feet are firmly on the ground, as he is both a victim of persecution and a sinner. He is also someone who is threatened by enemies and is then saved from them. In the psalms, he clings to God. The psalms are not concerned with his official duty as king; instead David is depicted as a figure with which to identify: 'as David, so every man' (Braulik 1995:71; Zenger 1998:41). (On David as an integration figure, see Millard 1994:230-234; cf. also Kleer 1996; Leuenberger 2004:172-206; Schuman 2008:162-165.)

The psalms linked to David's name make up a collection. These psalms have 'biographical' titles and, especially in the Books of Samuel, they are so intertwined with narratives that they are cast in a narrative mould (Zenger 1998:41).

Psalms 50 and 73-83 are associated with Asaph. In these psalms, the accent is on divine judgement, the divine oracles and an appeal regarding God's actions in the past. This all points to a prophetic background and reference can be made to 2 Chronicles 29:30; 1 Chronicles 25:1-6 and to the sons of Korah (Ps 42-49; 84-88). These psalms originated in the Jerusalem cult and the many references to Zion are clear proof
There is no doubt that the titles of the psalms were added to the texts later, as they reflect the historical conscience of the redactors of the psalms, rather than the historical foundation. The titles also serve to bind groups of psalms together where communal theological concepts can be distinguished (Zenger 1998:27). It has only been a few years since psalm scholarship acknowledged the fact that the canonical Psalter is the result of a complex process of collection as well as redaction. The attempt to explain the present shape of the Psalter is thus a relatively recent endeavour. Currently, the final form of the book of the psalms receives more attention and the idea of a somewhat haphazard arrangement has been questioned. Thus, interest in secondary settings of the psalms, including the literary context of the book as a whole, has increased. The emphasis of the reading is thus not on the individual psalm alone, but has shifted to a canonical reading of the individual psalm, i.e. on its respective position in the Psalter and, especially, the significance of its position for its interpretation (Hossfeld \& Zenger 1993:166-182; Schuman 2002:36-39; cf. also Groenewald 2003:277).

\section{The psalms as hymns}

The Book of the Psalms is the sanctuary where God is praised and from where his blessing is given. It in no way replaces the temple or the cult but instead represents an encounter with Yahweh residing in his temple on Zion as king of both Israel and the whole world (cf. Zenger 1998:47; Berges 1999:15).

There are three theopoetical ways to speak to God in the psalms: via the lament, the prayer or in praise (Spieckermann 2003:137; Gerstenberger 2003:76; see Schuman 2008:48-52 on the Psalms as a book of hymns). In Hebrew translations of the psalms, praise is distinguished contextually, but not semantically (Westermann 1977:20-28). We can find idioms in direct and indirect speech in the Psalms. There are also the actions of speech such as accusation, trust, self-reflection, the giving of praise to the king and to other people and so on. The three actions of speech, however, form the core of the psalms (Spieckermann 2003:137).

Praise in the hymns follows different patterns (Spieckermann 2003:137). There are hymns which call for praise by naming the supplicant and giving reasons for the praise (Psalms 100; 148). There are also hymns which make use of participia to describe God's nature (Ps 104; 147).

An entire anthropology is embedded in some of the hymns and is directed towards the praising of God (cf. Ps 8 and 103) (cf. Irsigler 1997:1-44 on Psalm 8; cf. also Strauß 2003:17-23). Psalm 23 is a psalm of trust and is woven with a delicate hymnal thread. Even the prayer of lament ends in praise (Ps 13). The hymnal function in the psalms of lament can be clarified with two examples. In Psalm 22 - an individual psalm of lament - verses 4-6 have the function of creating an antipode to the lament. In this manner, the individual history of suffering is inserted into the history of trust and the salvation of Israel. In Psalm 74 - a people's lament the hymnal core, verses $12-17$, creates hope after the catastrophe of 587-586 BCE by uniting with the temple theology of Jerusalem (Spieckermann 2003:138).

In the fourth and fifth Book of Psalms (Psalms 90-106; 107-150), the hymnal formulas and hymnal-woven text compositions increase (Zenger 1997a; Kratz 1996; Spieckermann 2003:142). The psalm-group 90-100 is a hymnal group, which celebrates the universal kingship of God. Psalm 96 deals with the question of how nations are expected to attain salvic knowledge. In Psalm 96, it becomes clear that it is expected that Israel's worship will have a particular effect on the nations (Psalm 96:1-4). Again, we notice the basic form of the hymn: imperative, addressee, vocative and $k \hat{\imath}$ (verses 1-4). However, the imperatives are liturgical only in part (three repetitions of 'sing'). They are followed by verbs, which characterise the form of speech usually directed at people outside the community of worship.

The poem refers to a messenger of victory, who informs people that do not know about the positive outcome of a battle, about 
Yahweh. More importantly, spr (verse 3) stands for the narrative of an individual who has been saved. It also stands for the worshipping service, to which he/she invites relatives and friends. It is fitting to express gratitude towards Yahweh, even at such a casual gathering. This involves thanking him (addressing him in the second person), and the telling of the salvation to the 'brothers' who need to learn this for themselves. The term 'new song' belongs to the category of a song of thanksgiving ( $c f$. Psalms 40:10; 144:9ff). This song is 'new', because it tells of Yahweh's new act of salvation.

In this way, the narrative of an individual who has experienced salvation in the context of worship becomes exemplary to the nations. The Psalm is not suggesting missionary action on the part of Israel, but is concerned with the effect of Israel's speech about Yahweh in the context of worship. The content of this speech revolves around Yahweh's glory, which is reflected in his deeds. Once again, the purpose of the psalm is not the relaying of these deeds as mere facts, but rather, it is the imparting of theological knowledge to the nations (Jeremias 2004:96; Leuenberger 2004:150-155).

Jeremias (2004:96-97; see also Millard 1994:147, 200, 207, 212 , 227; Leuenberger 2004:168-172) gives a penetrating account of the appeal to the nations to participate in the religion of Israel. In Psalm 100, the plural imperative of the basic form is used to invite the nations to participate in Israel's worship ('enter' is repeated twice in verses 2 and 4). The nations are not invited to just any form of worship, but to a festival of worship ('shout for joy' is a technical term for festival worship):

Shout for joy to Yahweh, all the earth!

Worship Yahweh with gladness;

come before him with joyful songs.

Know that the Lord is God.

It is he who made us, and we are his;

we are his people, the sheep of his pasture.

Enter his gates with thanksgiving,

and his courts with praise,

give thanks to him and praise his name.

For the Lord is good and his love endures forever; his

faithfulness continues through all generations.

(Psalm 100:1-5; New International Version)

The effect of such participation is formulated in the central imperative, which is placed between the two invitations (verse 3):

Acknowledge Yahweh, he is God.

He made us, and we are indeed

his people and the flock he shepherds.

This verse is very unusual, in so far as it dares to broaden the old formula of covenant, which is the central theme of Old Testament theology. Verse 3 cites the famous formula of the covenant according to Psalm 95:7 and Psalm 79:13 and then modifies it:

For he is our God,

and we are the people of his pasture,

a flock under his care.

(Psalm 95:7)

Then we, your people,

the sheep of your pasture,

will praise you for ever,

from generation to generation we will recount your praise.

The formula of covenant can be applied to the nations, because it is founded on the basis of a theology of creation. Psalm 95 assured Israel of its election and stressed the necessity of obedience. In contrast to election and obedience, Psalm 100 hints at creation and focuses on the knowledge of the nations, who are part of the worshipping congregation. This knowledge is based on the same assertion that is formulated in verse 3a: 'Only Yahweh is God.'

As in the famous confession of the nations in Isaiah 45:23, the First Commandment is broadened to refer to the nations. The First Commandment becomes the basis for the nation's knowledge of God, which they gain within the context of worship and from their knowledge of their own existence as beings of Creation. According to Psalm 100, the most important fact in all of this is that knowledge is not a prerequisite for participation in worship it is gained during acts of worship.

It is possible that Psalm 1 was created as a precursor to Psalms 90100 and, together with Psalm 2, it forms the hinge for the hymnal conclusion in Psalms 90-100 (Spieckermann 2003:143). Psalms 1 and 2 also function as a portal to the 'house' of the psalms (Schuman 2008:116-117, 130-131). The title of Psalm 90 as '(a) prayer of Moses the man of God', introduces Moses as the man who became one with the Torah. This unity fixes the Torah instruction as a way of life for Israel under the banner of a song of praise (Ps 1). This brings us to the point where praise of God as King is a universal injunction to all the earthly kings and nations (Spieckermann 2003:143). Israel already knows that because Yahweh is dwelling in Zion, the nations will learn by the destruction of their weapons: Yahweh alone is God (Ps 46:11). This knowledge is the basis for the integration of the nations into the worship of Israel by Psalm 100. When the nations are freed from their trust in weapons and their own power, they will be prepared for the truth of the worship of Israel, i.e. trusting in God alone (Jeremias 2004:98-99).

The self-summons to praise God, '(p)raise the lord, O my soul,' (Ps $103: 1,22 ; 104: 1,35)$, gives an individual-universal (Psalm 103) and royal, cosmic (Psalm 104) perspective on God's praise. Psalms 104106 are editorially linked by the jubilant invocation '(h)allelujah' (Ps 104:35; 105:45; 106:1, 48). Psalms 106 and 107 are linked by the introductory hymnal invocation, '(p)raise the Lord. Give thanks to the Lord, for he is good; his love endures for ever'(Ps 106:1; 107:1).

Psalms 105-107 are compositions that revolve around the history of salvation and the nation's catastrophes. The chorus of Psalm 107 is an incentive to praise God for his mercy and miracles (vs 8, 15, $21,31,43)$. The twin Psalms 111 and 112 have hymnal features. The composition of the two Psalms, as well as the twofold '(h)allelujah,' indicates that both should be read as texts of praise (Spieckermann 2003:144; Leuenberger 2004:292). The Egyptian hallel, Psalms 113-118, has an introductory '(h)allelujah' (on the Egyptian hallel, see Millard 1994:30-34; Schuman 2008:195-196, 204, 138). The '(h) allelujah' also reverberates in Psalms 115:18; 116:19 and 117:2. In Psalm 116, the hymn of thanksgiving and the votive offering are bound to the local sanctuary or the temple of Jerusalem, to where the sacrifice was brought (Janowski 2003:98; Leuenberger 2004:294).

Psalm 117 is the shortest psalm in the Old Testament. It evidently corresponds to the basic form of hymns of praise, namely the imperative, the addressee, the vocative, the $k \hat{\imath}$ and the verb 'great is' (gabal) in the perfect.

Praise Yahweh, all you nations;

extol him, all you peoples.

For great is his love towards us,

and Yahweh's faithfulness endures for ever. Hallelujah.

However, there are three important digressions from the usual form (Jeremias 2004:95-96; Leuenberger 2004:294):

- $\quad$ The imperatives at the beginning are no longer liturgical in a realistic manner. The people called upon to praise Yahweh are not present; instead, Israel is representing them. It is implied that the whole world should worship Yahweh, because he is the King of the World. However, this is an eschatological perspective and, for the time being, the congregation is worshipping in a representative way.

- The nations did not personally experience the God of the Bible. However, the experiences of Israel are enough to call upon the nations to take part in the praising of Yahweh. This Psalm raises the question of how the nations should come to their own knowledge of God. 
- $\quad$ Since the Psalm is touching on a basic problem, instead of an enumeration of deeds of Yahweh (as is the case in Ps 136), only the essential knowledge derived from his deeds is mentioned, namely his attributes of kindness and trustworthiness. The nations can participate in worship only when they possess a basic knowledge of these attributes. For the time being, Yahweh's kindness is only being experienced by Israel and will only be experienced by the nations at a later stage.

Psalm 118 is well known because it is part of the Easter liturgy (Schuman 2008:59). This Psalm starts and ends with '(g)ive thanks to the Lord, for he is good. For his love endures for ever.' This forms an inclusio. The difference is apparent, however, in that the elements of a collective hymn are almost absent, while elements which are usually part of a song of thanksgiving form the centre of the Psalm (Millard 1994:53, 80; Leuenberger 2004:295). Although Psalm 118 is a thanksgiving psalm, it nevertheless contains hymnical elements (cf. the inclusio, verses 1 and 29). Thanksgiving is an important way of praising Yahweh. The congregation which is singing this hymn is giving praise from an individual perspective. Since the songs of thanksgiving tend to include didactic elements, the congregation is instructed to learn about Yahweh through individual salvation. Hence, the connection between the praising of Yahweh and the congregation's knowledge of Yahweh can easily be grasped (Jeremias 2004:93-94; cf. Schuman 2008:196).

Give Yahweh thanks for he is good;

his love endures for ever (verse 1).

From my anguish I cried to Yah(weh)

And he answered me

by setting me free.

Yahweh is with me:

I will not be afraid.

What can men do to me?

Yahweh is with me;

he is my helper.

I will look in triumph on my enemies.

It is better to take refuge in Yahweh

than to trust in man.

It is better to take refuge in Yahweh

than to trust in princes.

(verses 5-9)

Verse 5 contains the narrative of the salvation of an individual in need. Once again, this narrative is extremely short - there is no biographical detail. Yet, it contains some of the most beautiful images in the entire Old Testament. The individual's need is likened to a situation of confinement and salvation to a large and free space in which movement in all directions is possible (Jeremias 2004:94).

The consequences are given in greater detail in verses 6-9. Also, the knowledge which the congregation can glean from this individual's experience is described. Two pairs of verses are used - the first (vs 6) is written in the first person, the second (vs 8) in a generalised didactic style. This second pair of verses takes up a common subject in the discourse of the Old Testament, namely the difference between trusting Yahweh and trusting man's power. With regard to the latter, influential persons are named, whereas 'horses' (Is 31:3 et seq.) or 'young men' in their prime (Is 40:30 et seq.) usually fulfil this role. Here, the values of life are exchanged with the hymn of festival worship.

Circumstances that are seemingly evident, such as the use of power, the idealisation of youthful strength and the relationship with important people all appear as failure. Placing trust in God, though seemingly uncertain, is presented as the true foundation of life (Jeremias 2004:94).

Psalm 134 concludes the collection of pilgrimage psalms (120-134) (Millard 1994:27, 40-41; cf. Schuman 2008:197), with a hymnal call: 'Behold, bless the Lord ...' (Ps 134:1-2). Psalm 135 corresponds to Psalm 134 (cf. Ps 135:1 et seq., 19-21), while the antiphonal hymn, Psalm 136, corresponds to Psalm 135 (cf.
Psalm 135:3 to 136:1). The hymnal echo '(g)ive thanks to the Lord, for he is good. His love endures for ever' (Psalm 136:1) also reverberates in Psalms 106 and 118. In Psalm 136 there are quite a number of peculiarities. Jeremias (2004:93) mentions the most important ones (cf. also Millard 1994:14, 15, 33, 39, 40, 78-79, 203; Human 2004:73-88; Leuenberger 2004:280, 316-320; Schuman 2008:118, 197):

- Psalm 136 is a litany; the congregation answers the different sections of the poem with a refrain.

- It comprises a long list of God's deeds, which are enumerated by the grammar of the participles. Thus, the Psalm consists of one single sentence.

- The different deeds of God belong to the category of miracles (verse 4); this verse forms a kind of hermeneutic superscription

- A noticeable polemical atmosphere is present in the poem; verses 2-3 provide it in the form of a superlative, while verse 4 stresses God's incomparability: 'he alone.' The First Commandment with its differentiation of powers forms the basis of this sentence.

More important than these observations is the theological knowledge out of which the refrain evolves. This refrain dares to say, 'his love is everlasting.' The refrain implies that it is possible to say things about God that will remain valid forever, based on the experiences which the Psalm enumerates. The refrain implies that Israel did not experience Yahweh's kindness only on some occasions, but always and continuously, even when the people did not notice anything (Jeremias 2004:93).

This is a rather keen assertion and it is clear that it cannot be supported by a single experience of God, but only by a chain of linked experiences (which are given in the canonical order: exodus - desert-land, verses 10-22). This chain of experience even reaches into the present (vs 23-25), and it starts with the Creation (vs 6-9), which qualifies as the first-ever act of God in history (Human 2004:77, 79, 80-83).

Each of these experiences is in itself a 'miracle,' each of these experiences bears witness to the truth of the First Commandment (vs 4). Yet, according to the hymn, only these experiences can have 'everlasting' consequence. This consequence is emphasised as special, given the specific undertones of the term $h s d$, which denotes not only the kindness of God, but also implies an element of the unexpected, and an abundance of experiences of God (Groenewald 2003:81; Jeremias 2004:93).

A series of prayers principally attributed to David (Ps 137-144), in which the lament dominates, culminate in the acrostic Psalm 145. In this Psalm, praise for the Lord, who commands royal power, is declared. His kingship is for all times and encompasses all generations (Ps 145:11-13). In Psalms 146-150, hymnal sounds vibrate. These Psalms begin and end with '(p)raise the Lord.'Each hemistich in Psalm 150 breaks out in a '(h)allelujah' (Loader 1991:165; Schuman 2008:141-142; Spieckermann 2003:144). Due to the precise regularity with which the exclamation '(h) allelujah'appears, the page layout or visual appearance of the printed poem emphasises the laudatory character of the song (Leuenberger 2004:358-364; Loader 1991:165). The entire Psalm 150 is a hymn.

The praise has a theopoetical function, because giving praise is part of life. Praise and the lack of praise face each other as life and death (Von Rad 1966:381). For biblical Israel, life was impossible without giving praise to God. The Old Testament reiterates the following sentence: 'The dead ones do not praise God.' This sentence is not primarily concerned with the dead, but with those still living. If there is no giving of praise, there is no life. If no praises are sung, the power of death penetrates life (Jeremias 2004:99). Therefore, giving praise is the meaning of life:

Let me live that I may praise you,

and may your laws sustain me.

(Psalm 119:175) 
I will not die but live, and will proclaim

what Yah(weh) has done.

Giving praise becomes the most elementary characteristic of being alive. However, one has to be wary of one particular dangerous situation:

Praise Yahweh, O my soul;

all my inmost being

praise his holy name.

Praise Yahweh, O my soul,

and forget not all his benefits -

who forgives all your sins

and heals all your diseases,

(Psalm 103:1-3)

The Psalm warns that people who forget to praise God lose part of their lives. Forgetting is not merely an intellectual act - it can also involve an orientation on the part of both humans and God towards life. The best example of this can be found in Psalm 25:6-7:

Remember, Yahweh, your great mercy and love,

for they are from of old.

Remember not the sins

of my youth

and my rebellious ways;

If God were to remember all the transgressions of the youth, nobody would survive. Instead, the congregation hopes that God will remember them with mercy. Remembering God's deeds is so important in the hymns of the Bible that later hymns in the Old Testament combine the call for praise with the call to remember. The beginning of Psalm 105 may serve as an example.

Give thanks to Yahweh,

call on his name;

make known among the nations

what he has done.

Sing to him, sing praise to him;

tell of all his wonderful acts.

Glory in his holy name;

let the hearts of those

who seek Yahweh rejoice.

Look to Yahweh and his strength;

seek his face always.

Remember the wonders

he has done,

his miracles, and the judgments

he pronounced,

$O$ descendants of Abraham

his servant

O sons of Jacob, his chosen ones.

(verses 1-6)

This Psalm combines the necessity to impart to the nations knowledge of Yahweh's deeds during worship (vs 1) with the importance of reflection (vs 2) and remembering God's miracles (vs 5). Reflection and remembering are ideally practised in a sacred place and within the community of worship (vs 4), rather than the privacy of one's own home. Such worship helps to prevent man from forgetting (Jeremias 2004:100).

Contrary to Zenger's (2000:434) opinion that the Psalter is a layman's book of eschatological knowledge of life, Spieckermann (2003:158) regards it as a book, a scroll, that was in the hands of the priests and scribes. There it became an authoritative agent, a source of insight and an inspiration for theological practise (theopoetry) when praising God. These two viewpoints need not exclude each other totally. The possibility could thus even be considered - as has already been stated - that Levitical groupings were responsible for the 'levitical' compilation of the Psalter. However, the possibility exists that at a later stage of its development it eventually ended in the hands of some priestly groupings. They were then finally responsible for the canonical positioning of the Psalter: they thus accorded it with canonical status. The Psalter, as a book encompassing all experience, managed to reach the ordinary people, even though it was in the possession of priests and scribes.

In the time of Jesus, although the psalms were not the official liturgical songs and prayer books of the Jewish congregation in the temple and synagogue services (Barnard 1985:146; Füglister 1988:329-352), they were sung by a guild of vocalists, accompanied by musicians. The hallel was sung (Psalms 113118) during Passover (also the Feast of the Tabernacles). Here, we could also refer to the song of praise in Matthew 26:30, which was sung after the Holy Communion. On the way to the temple for Pentecost or the Feast of the Tabernacles, pilgrimage songs were sung (Ps 120-134). The joy of the Torah was a further reason for jubilation (Ps 1; 19; 119), and before the Sabbath morning, Psalm 72 was sung (Barnard 1985:583; Albrecht 1987:9; Strydom 1994:20-21).

\section{PSALMS TUNED INTO LITURGY}

Neither the Old nor the New Testament presents a rigid, prescribed form into which the liturgy should be moulded (Vos \& Pieterse 1997:29). During the ages, however, a living Christian tradition came into being from, among others, the primal sources of the Old and New Testament and the later traditions of the Church (Barnard 1985:66-383; Schuman 1998a:26-36). These traditions have a definitive character. Certain patterns, colours and sounds are noticed. However, each generation of believers must interpret the ancient sources and traditions of the Church anew, within the demands of their time, without being unfaithful to the traditions in which a definitive liturgy exists.

The liturgy is the science of Christian rites and symbols (Barnard 2000:5). When the Psalter becomes part of the liturgical system, it must comply with the requirements of the liturgical ritual. The choice of psalms is determined not only by the liturgical tradition, but also by various exegetical points of view (Braulik \& Lohfink 2003:236; Vos 2005:358). This means that the liturgical 'colour' of every psalm must be perceptible.

The liturgist must also attune his ear to the 'voice' of every hymn, so as to be able to 'colour' the liturgy with psalms. A certain hymn may be better applied in one particular liturgical place than in another. The hymns can also be sung before the votum. Another meaningful place to use the hymns would be after the benediction - this is the liturgical place where the congregation stands with their faith before the Living Lord.

From the above it should be clear that the psalm as hymn can enrich the liturgy immensely. God's praise can be heard anywhere.

\section{CONCLUSION}

The psalms as hymns is a treasury with which God can be praised anywhere and under any circumstances. The Christian Church has also utilised the hymns of the Psalter. Therefore, we as Christians may also live and sing the ancient songs. In the hymns, the Lord God is in the centre and, in praising him, the faithful find peace. He deserves the community of faith's worship for he is gracious, merciful and loving.

\section{REFERENCES}

Albrecht, C., 1987, Einführung in die Hymnologie; 3, Vandenhoeck \& Ruprecht, Göttingen.

Barnard, A.C., 1985, Die erediens; 2de druk, NG Kerkboekhandel, Pretoria.

Barnard, M., 2000, Liturgiek als wetenschap van christelijke riten en symbolen, Vossiuspers AUP, Amsterdam.

Berges, U., 1999, De armen van het boek Jesaja: Een bijdrage tot de literatuur-geschiedenis van het Oude Testament, Universiteit Nijmegen, Nijmegen. 
Braulik, G., 1995, 'Christologisches Verständnis der Psalmen schon im Alten Testament?', in K. Richter \& B. Kranemann (Hrsg.), Christologie der Liturgie. Der Gottesdienst der Kirche - Christusbekenntnis und Sinaibund, pp. 57-86, Herder, Freiburg.

Braulik, G., 2003, 'Psalms and liturgy: Their reception and contextualisation', Verbum et Ecclesia 24(2), 309-330.

Braulik, G. \& Lohfink, N., 2003, Osternacht und Altes Testament, Lang, Wien.

Childs, B.S., 1971, 'Psalm titles and midrashic exegesis', JSSt 16(2), 137-150.

Füglister, N., 1988, 'Die Verwendung und das Verständnis der Psalmen und des Psalters um die Zeitenwende', in J. Schreiner, (Hrsg.), Beiträge zur Psalmenforschung: Ps 2 und 22, 319-384, Echter Verlag, Würzburg.

Gerstenberger, E.S., 2003, 'Psalmen und Ritualpraxis', in E. Zenger (Hrsg.), Ritual and poesie, pp. 73-90, Herder, Freiburg.

Groenewald, A., 2003, Psalm 69: Its structure, redaction and composition, Lit Verlag, Münster.

Hossfeld, F-L. \& Zenger E. (Hrsg.), 1993, Die Psalmen: Psalmen 1-50, Echter Verlag, Würtzburg.

Hossfeld, F-L. \& Zenger E. (Hrsg.), 2000, Die Psalmen: Psalmen 51-100, Herder, Freiburg.

Human, D.J., 2004, 'Psalm 136: A liturgy with reference to creation and history', in D.J. Human \& C.J.A. Vos (eds.), Psalms and Liturgy, pp. 73-88, T \& T Clark, London.

Irsigler, H., 1997, Von Adamssohn zum Immanuel, EOS Verlag St, Ottilien.

Janowski, B., 2003, 'Dankbarkeit - Ein antropologischer Grundbegriff im Spiegel der Toda-Psalmen', in E. Zenger (Hrsg.), Ritual und poesie, pp. 90-136, Herder, Freiburg.

Jeremias, J., 2004, 'Worship and theology in the Psalms', in D.J. Human \& C.J.A. Vos (eds.), Psalms and liturgy, pp. 89-101, T \& T Clark, London.

Jonker, L.C., 2004, 'Revisiting the Psalm headings: Second temple levitical propaganda?', in D.J. Human \& C.J.A. Vos (eds.), Psalms and liturgy, pp. 102-122, T \& T Clark, London.

Kaspar, P.P., 1999, Musica sacra: Das grosse Buch der Kirchenmusik, Styria, Graz.

Kleer, M., 1996, "Der liebliche Sänger der Psalmen Israels": Untersuchungen zu David als Dichter und Beter der Psalmen, Philo, Bodenheim.

Kratz, R.G., 1996, 'Die Torah Davids: Psalm 1 und die doxologische Fünfteilung des Psalters', ZThk 93, 1-34.

Liedboek van die Kerk, 2001, NG Kerk Uitgewers, Kaapstad.

Leuenberg, M., 2004, Konzeptionen des Königtums Gottes im Psalter, Theologischer Verlag, Zürich.

Loader, J.A., 1991, 'God se hemelgewelf', in C.J.A. Vos \& J.C. Müller (reds.), Mens en omgewing, pp. 164-173, Orion, Halfway House.

Lohfink, N., 2000, Im Schatten deiner Flügel: Grosse Bibeltexte neu erschlossen, Herder, Freiburg.
Lohfink, N., 1993, 'Was wird anders bei kanonischer Schriftauslegung? Beobachtungen am Beispiel von Psalm 6,' Studien zur biblischen Theologie, pp. 263-293, Katholisches Bibelwerk, Stuttgart.

Millard, M., 1994, Die Komposition des Psalters: Ein formgeschichtlicher Ansatz, JCB Mohr, Tübingen.

Monshouwer, D., 1998, 'Informatie en documentatie', in P. Oskamp \& N. Schuman (reds.), De weg van de liturgie: Tradities, achtergronden, praktijk, pp. 423-435, Meinema, Zoetermeer.

Schuman, N.A., 1995, 'En wat zij zong hoorde Ik dat psalmen waren': Over psalmen en liturgie, Intreerede, 22 September 1995, Kampen.

Schuman, N.A., 1998a, 'De Psalmen', in P. Oskamp \& N. Schuman, (reds.), De weg van de liturgie: Tradities, achtergronden, praktijk. 165-175, Meinema, Zoetermeer.

Schuman, N.A., 1998b, "“... Die weet gehad heeft en geen weet gehad"', Skrif en Kerk 19(2), 373-380.

Schuman, N.A., 2001, 'Psalm 91: tekst, context, en een diversiteit aan herlezingen', in P. Post, G. Rouwhorst, T. Sheer, R. Steensma \& L. Tongeren (reds.), Jaarboek voor liturgieonderzoek deel 17, pp. 237-256, Instituut voor Liturgie-wetenschap, Groningen.

Schuman, N.A., 2002, Pastorale: Psalm 23 in Bijbel en Liturgie verwoord en uitgebeeld, Meinema, Zoetermeer.

Schuman, N.A., 2008, Drama van crisis en hoop: De psalmen: Gedicht, gebundeld en gebeden, Meinema, Zoetermeer.

Spieckermann, H., 2003, 'Hymnen im Psalter - Ihre Funktion und ihre Verfasser', in E. Zenger (Hrsg.), Ritual und poesie, pp. 90-136, Herder, Freiburg.

Strauß, H., 2003, ....eine kleine Biblia: Exegesen von dreizehn ausgewählten Psalmen Israels, Neukirchener Verlag, Neukirchen.

Strydom, W.M.L., 1994, Liturgie en lied: "Sing nuwe sange, nuutgebore", NG Sendingpers, Bloemfontein.

Van Oort, H., 1991, Augustinus' facetten van leven en werk, Kok, Kampen.

Von Rad, G., 1966, Theologie des Alten Testaments. Band I; 5, Auflage, Chr. Kaiser, München.

Vos, C.J.A., 2001, ' 'n Perspektief op die nuwe Psalmomdigting', HTS Teologiese Studies/Theological Studies 56(2\&3), 357-376.

Vos, C.J.A., 2005, Theopoetry of the Psalms, T \& T Clark, London.

Vos, C.J.A. \& Pieterse, H.J.C., 1997, Hoe lieflik is u woning, RGN Uitgewers, Pretoria.

Westermann, C., 1977, Lob und Klage in den Psalmen, Vandenhoeck \& Ruprecht, Göttingen.

Zenger, E., 1997, Die Nacht wird leuchten wie der Tag: Psalmenauslegung, Akzente, Freiburg.

Zenger, E., 1997a, “'Daß alles Fleisch den Namen seiner Heiligung segne" (Ps 145, 21): Die Komposition Ps 145-150 als Anstoß zu einer christlich-jüdischen Psalmen-hermeneutik', BZ 41, $1-27$.

Zenger, E., 1998, Der Psalter in Judentum und Christentum (FS für Norbert Lofhink), Herder, Freiburg.

Zenger, E., 1998b, Einleitung in das Alte Testament, Herder, Freiburg. 